\title{
SQSTM1 wt Allele
}

National Cancer Institute

\section{Source}

National Cancer Institute. SQSTM1 wt Allele. NCI Thesaurus. Code C101492.

Human SQST M1 wild-type allele is located $5 \mathrm{q} 35$ and is approximately $32 \mathrm{~kb}$ in length. This allele, which encodes sequestosome-1 protein, plays a role in signal transduction. Mutation of the gene is associated with Paget disease of bone. 